\title{
Quantifying the Benefits of Estuarine Habitat Restoration in the Gulf of Mexico: an Introduction to the Theme Section
}

\author{
Melissa Vernon Carle ${ }^{1}$ (D) Kristopher G. Benson $^{2}$ (D) $\cdot$ James F. Reinhardt $^{1}$ (B)
}

Received: 10 April 2020 / Revised: 10 July 2020 / Accepted: 15 July 2020 / Published online: 31 July 2020

(C) The Author(s) 2020

\begin{abstract}
This collection of papers provides insights into methods and data currently available to quantify the benefits associated with estuarine habitat restoration projects in the northern Gulf of Mexico, USA, with potential applicability to other coastal systems. Extensive habitat restoration is expected to occur in the northern Gulf of Mexico region over the next several decades through funding associated with the 2010 Deepwater Horizon oil spill. Papers in this section examine the development of vegetation, soil properties, invertebrate fauna, and nekton communities in restored coastal marshes and provide a conceptual framework for applying these findings to quantify the benefits associated with compensatory marsh restoration. Extensive meta-analysis of existing data for Gulf of Mexico coastal habitats further confirms that structured habitats such as marsh, submerged aquatic vegetation, and oyster reefs support greater nekton densities than nonvegetated bottom habitat, with oyster reefs supporting different species assemblages than marsh and submerged aquatic vegetation. Other papers demonstrate that while vegetation cover can establish rapidly within the first 5 years of restoration, belowground parameters such as root biomass and soil organic matter remain $44 \%$ to $92 \%$ lower at restored marshes than reference marshes 15 years after restoration. On average, amphipod and nekton densities are also not fully restored until at least 20 and 13 years following restoration, respectively. Additional papers present methods to estimate the benefits associated with marsh restoration projects, nekton productivity associated with coastal and estuarine habitats, and the benefits associated with the removal of derelict crab traps in Gulf of Mexico estuaries.
\end{abstract}

Keywords Ecological restoration $\cdot$ Coastal habitats $\cdot$ Restoration trajectories $\cdot$ Habitat equivalency analysis

\section{Introduction}

A common goal of ecological restoration is to establish habitat that is self-sustaining and resembles natural conditions in both structure and function (Thayer et al. 2003; Turner and Streever 2002). While restoration practitioners have made significant advances toward replicating the structure of natural habitats,

Communicated by Paul A. Montagna

Melissa Vernon Carle

melissa.carle@noaa.gov

1 Restoration Center, Office of Habitat Conservation, National Marine Fisheries Service, National Oceanic and Atmospheric Administration, 1315 East-West Highway, Silver Spring, MD 20910, USA

2 Restoration Center, Office of Habitat Conservation, National Marine Fisheries Service, National Oceanic and Atmospheric Administration, 4700 Avenue U, Bldg. 307, Galveston, TX 77551, USA key questions remain about how to re-establish and sustain key ecological functions over time. These questions include the following: (1) to what extent do mature restoration projects function similarly to natural habitats?; (2) what is the rate of development for specific ecological functions?; (3) what additional data are needed to reduce uncertainty in the rates of development of ecological functions?; (4) what restoration actions might increase the rates of development for desired functions?; and (5) are there synergies between different types of restoration projects that enhance restoration outcomes?

Many early coastal restoration projects focused on manipulating physical conditions and establishing habitat structure. Less effort was given to addressing whether restoration interventions resulted in similar ecological functions as natural habitats. Some ecological functions can take years to decades to develop or may never fully reach the level of natural reference habitats (McGlathery et al. 2012; Moreno-Mateos et al. 2012; Zedler and Callaway 1999). The restoration trajectory or the rate of development of ecological structure and functions and the time required for restored habitats to resemble to 
natural habitats, can have important implications for setting realistic expectations and calculating compensatory restoration requirements (e.g., Fonseca et al. 2000; Strange et al. 2002). Better understanding the trajectories associated with the restoration project development may also help restoration practitioners identify project features or approaches that speed the development of important functions and services (e.g., Karp et al. 2018; Madrid et al. 2012; Reynolds et al. 2012; Silliman et al. 2015). It can also help identify when to directly restore specific lost ecosystem functions (McCay et al. 2003) or prioritize the conservation of existing high function habitats (e.g., Beck and Odaya 2001; Levin and Stunz 2005), rather than conduct habitat restoration.

Extensive restoration of estuarine habitats will occur in the northern Gulf of Mexico (GOM), USA region over the next several decades through over $\$ 16$ billion in funding provided by penalties and settlement agreements associated with the 2010 Deepwater Horizon oil spill (Deepwater Horizon Natural Resource Damage Assessment Trustees 2016; Gulf Coast Ecosystem Restoration Council 2016). This substantial investment in coastal habitat restoration is intended to provide broad ecosystem benefits, including provision of food, shelter, and spawning and nursery areas, to help restore the wide range of species and life stages that were injured by the spill. A better understanding of the ecological benefits of coastal habitat restoration projects can help managers compare projects and project designs and assist with the selection of projects that maximize benefits to the range of species and habitats targeted for restoration. With these goals in mind, this theme section presents seven papers that synthesize the existing data on the restoration of coastal habitats in the GOM. The papers identify gaps where additional data collection would improve the understanding of functional development and benefits to associated faunal resources, providing a foundation for future restoration work in the region and an approach that could be applied in other regions.

\section{How Do Restored Coastal Habitats Compare with Natural Habitats?}

For restored coastal marshes, habitat structure can develop quickly following restoration (Armitage et al. 2014; Cui et al. 2009; Edwards and Proffitt 2003; Virgin et al. 2020). Structure, however, does not always correlate with functions such as organic matter accumulation, nutrient transformation, or benthic invertebrate community characteristics (Cole 2002; Meli et al. 2014). Soil properties, including organic matter and nutrients, are particularly slow to develop in restored wetlands (Armitage et al. 2014; Craft et al. 2002; Cui et al. 2009; Edwards and Proffitt 2003; Llewellyn and La Peyre 2011; Morgan and Short 2002; Yu et al. 2017). In this issue, Ebbets et al. (2020) corroborate these findings, suggesting that for marsh restoration projects in the GOM, average belowground biomass and soil organic matter do not reach reference levels until more than 30 years after restoration is complete. The slow accumulation of soil organic matter may drive differences in benthic communities observed between restored and reference marshes, which can persist for decades following restoration (Craft et al. 1999, 2003; Craft and Sacco 2003; Levin et al. 1996; Minello and Webb 1997; Staszak and Armitage 2013; Streever 2000; Swamy et al. 2002; Zimmerman et al. 1979). The relatively slow development of salt marsh invertebrate communities in restored marshes is highlighted by the results of Baumann et al. (2020), who found that amphipod communities do not fully recover until more than 20 years following restoration.

Coastal marshes provide important functions for fish and invertebrate species, serving as spawning and nursery habitat, providing refuge from predators, foraging habitat, and environmental conditions that enhance survival and/or growth (e.g., overwintering habitat) (Beck et al. 2001; Boesch and Turner 1984; Deegan et al. 2002; Lefcheck et al. 2019; Rountree and Able 2006). These functions may not develop at the same rate at restored marsh sites (Meli et al. 2014). Gut content analyses and correlations between nekton density and soil organic content and benthic invertebrate densities suggest that trophic support functions may sometimes develop more slowly than other nekton habitat functions, driven by slow development of benthic infauna and epifauna communities (Allen et al. 1994; Minello and Zimmerman 1992; Warren et al. 2002; Zeug et al. 2007). Some studies suggest that it takes longer to achieve comparable nekton sizes, growth rates, and/or diet compared with reference marshes (Allen et al. 1994; Moy and Levin 1991; Warren et al. 2002; Weinstein et al. 2019; Zeug et al. 2007), but there are also conflicting examples (Llewellyn and La Peyre 2011; Rozas and Minello 2009; Simenstad and Thom 1996). Such delays are observed more often in marshes created using dredged material with low organic content. By contrast, many tidally restricted marshes show rapid development of sediment organic content, benthic invertebrates, and nekton feeding patterns and growth once flooding has been re-established (Able et al. 2008; James-Pirri et al. 2001; Lechene et al. 2018; Miller and Able 2002; Nemerson and Able 2005; Teo and Able 2003a, b; Tupper and Able 2000; Weinstein et al. 2019).

In general, nekton communities establish rapidly at restored marsh sites, with restored marshes capable of supporting nekton densities and community compositions similar to natural marshes as quickly as 1 to 2 years following restoration (Able et al. 2008; Dionne et al. 1999; Jivoff and Able 2003; Konisky et al. 2006; Lechêne et al. 2018; Nemerson and Able 2005; Raposa and Talley 2012; Roman et al. 2002; Simenstad and Thom 1996; Williams and Zedler 1999). However, this is not always the case for restored marshes or all species (Havens et al. 2002; Minello 2000; 
Minello and Webb 1997; Moy and Levin 1991; Streever 2000). In this issue, Hollweg et al. (2020b) use a metaanalysis approach to re-examine data from paired restoration and reference sites in the northern GOM region. They find that mean nekton densities at restored sites do not achieve equivalence with reference sites until 13 years after restoration, a trend that is strongly driven by lower crustacean densities at restored sites (Hollweg et al. 2020b). Some of the variability observed in nekton community establishment at created marshes may be attributed to factors such as the type of dredged sediments used, marsh elevations, rates of sediment organic matter accumulation, and benthic community development (Minello and Webb 1997; Thom et al. 2004; Zeug et al. 2007). Project-specific features such as tidal connectivity, substrate variability, shallow ponds, and the amount of marsh edge habitat can also have a strong influence on the functions of restored wetlands (Larkin et al. 2008; Minello and Webb 1997; Weinstein et al. 2005; Zeug et al. 2007).

Restoration outcomes for submerged aquatic vegetation (SAV) beds have been variable. Recent reviews of SAV restoration outcomes from Chesapeake Bay and Europe and a global meta-analysis of SAV restoration found that few restored sites survive beyond 1 year (Cunha et al. 2012; Luckenbach et al. 2011; van Katwijk et al. 2016). The results of these reviews contrast with numerous individual studies over the past few decades that have documented examples of successful SAV restoration (Bell et al. 2014; Fonseca et al. 1996a; Kenworthy et al. 1980; McSkimming et al. 2016; Sheridan 2004). In some cases, monitoring timeframes much longer than 3 years may be necessary to fully capture the restoration trajectories of SAV beds ( Bell et al. 2008, 2014; McGlathery et al. 2012).

Appropriate site selection is particularly important for SAV restoration, as water quality and water clarity are important drivers of restoration outcomes (Golden et al. 2010; Luckenbach et al. 2011; Orth et al. 2010; van Katwijk et al. 2016). Loss of historic SAV beds can create feedbacks with water flow velocity that can increase turbidity and make it difficult for SAV to re-establish, potentially explaining the high failure rate for SAV restoration attempts (van der Heide et al. 2007). The range of techniques that have been used for SAV restoration complicates the development of restoration trajectories for SAV beds. For example, seeding can result in different outcomes from transplanting (Fonseca et al. 1990; van Katwijk et al. 2016) and the timing of planting, interannual variability in environmental conditions, use of fertilization, and genetics of the donor stock can also influence outcomes (Bologna and Sinnema 2012; Jahnke et al. 2015; Kenworthy et al. 2018; Orth et al. 2009; Powell et al. 1991; Reynolds et al. 2012). However, nekton and epifauna can respond rapidly to successful SAV restoration, with abundance/density, species composition, and size at restored sites resembling those of natural SAV beds within a couple of years
(Fonseca et al. 1990, 1996b; McSkimming et al. 2016; Scapin et al. 2016; for exceptions, see Sheridan et al. 2003). Colonization by resident epibenthic fauna may be dependent on the restored bed first reaching a minimum shoot density (Fonseca et al. 1990, 1996b).

By contrast, restored oyster reefs tend to demonstrate rapid development of both ecosystem structure and function, as long as they are located in environmental settings with suitable salinity, water quality, and oyster larval transport (Beseres Pollack et al. 2012; Powers et al. 2009). Under the right conditions, restored eastern oyster (Crassostrea virginica) reefs have been shown to support similar oyster densities as natural oyster reefs within just a few years, with examples from the GOM (Chambers et al. 2017; Dillon et al. 2015; Frederick et al. 2016; La Peyre et al. 2014; Rezek et al. 2017), South Carolina (Hadley et al. 2010), North Carolina (Hanke et al. 2017; Keller et al. 2019; Meyer and Townsend 2000), and Chesapeake Bay (Schulte et al. 2009). Similar outcomes have also recently been reported for other oyster species in Australia (Shelamoff et al. 2019).

Many restored oyster reefs support similar resident macrofauna abundance, species richness/diversity, and biomass as natural oyster reefs within a few years following construction (Hadley et al. 2010; Harwell et al. 2011; Karp et al. 2018; Meyer and Townsend 2000; Rezek et al. 2017). While few published studies have compared the nekton communities of constructed oyster reefs with natural reference reefs, studies in North Carolina found similar nekton community characteristics between created and natural reference reefs (Harwell et al. 2011; Meyer and Townsend 2000; Rutledge et al. 2018). Numerous studies have demonstrated enhanced nekton abundance on restored oyster reefs compared with unstructured control sites (Chowdhury et al. 2020; Gilby et al. 2019; Humphries and La Peyre 2015; La Peyre et al. 2014; Scyphers et al. 2011). Food web characteristics such as food chain length, food web complexity, and consumer stable isotope values have also been demonstrated to be similar between restored oyster reefs and natural reef communities within 2 years following restoration in some cases (Dillon et al. 2015; Rezek et al. 2017).

It has been well established that each of these coastal habitats (marsh, SAV, oyster reefs) individually provide important benefits to estuarine resident and transient nekton species, as well as to other species that benefit from exported prey (Able 2005; Blandon and zu Ermgassen 2014; Boesch and Turner 1984; Deegan 1993; Jänes et al. 2020; Nelson et al. 2011; Odum 1980; Weinstein et al. 2005, 2014; zu Ermgassen et al. 2016). In this issue, Hollweg et al. (2020a) reinforce that these structured habitats support higher nekton densities than unstructured habitat, with oyster reefs generally supporting different nekton communities than marsh and SAV. There is also evidence that restoration of multiple habitat types in close proximity to each other can result in higher nekton 
biodiversity and production than the restoration of each individual habitat in isolation (Baillie et al. 2015; Irlandi and Crawford 1997; Meynecke et al. 2008; Zeug et al. 2007). While some studies suggest that restored oyster reef habitat can be functionally redundant to other structured habitats (Geraldi et al. 2009; Grabowski et al. 2005; La Peyre et al. 2014), the presence of patchy oyster substrate along the marsh edge may enhance marsh habitat value for some species (Zeug et al. 2007).

Given that different habitats are used by different nekton species and life stages (Glancy et al. 2003; Rozas and Minello 1998; Rozas and Zimmerman 2000; Stunz et al. 2002, 2010), protecting and/or restoring a heterogeneous mosaic of coastal habitats within estuaries should support successful niche partitioning. Heterogeneity within habitats can also contribute to enhanced ecological function and service flows. For example, microhabitats within coastal marshes (e.g., interior marsh surface, marsh edge, tidal creeks, shallow ponds, and adjacent non-vegetated bottom) support different nekton densities and species compositions (Baltz et al. 1993; Breitburg et al. 1995; Minello and Rozas 2002; Minello et al. 1994; Peterson and Turner 1994). In this issue, Hollweg et al. (2020a) support these findings for marshes in the northern GOM, with total nekton density highest in marsh edge habitat and differing nekton community composition between marsh edge, marsh interior, and non-vegetated bottom habitats.

\section{Applying Restoration Trajectories to Compensatory Restoration}

Trajectories describing the rate of development of ecological functions can be used to quantify the scale of restoration needed to offset habitat injuries in regulatory contexts. Habitat equivalency analysis (HEA) and resource equivalency analysis (REA) are approaches that have been developed to assist with calculating the amount of restoration needed to compensate for injuries to natural resources (English et al. 2009; NOAA 1995, 1997). The main distinction between HEA and REA is that HEA is usually applied to habitat types (e.g., tidal marsh or oyster reefs) while REA is applied to specific living resources (e.g., number of injured birds or biomass of injured fish). These methods were originally developed in the USA for use in Natural Resource Damage Assessments (NRDAs) for oil spills, but they have also been applied to chemical spills, vessel groundings, forest fires, and habitat conversion (Desvousges et al. 2018; Fonseca et al. 2000; Kirsch et al. 2005). The European Union has also adopted HEA and REA for calculating environmental mitigation requirements (Desvousges et al. 2018; Lipton et al. 2018), and the United Nations relied on HEA to determine compensation for environmental damages in Kuwait from the 1990 to 1991 Gulf War (United Nations Security Council 2005).
Past HEA and REA models have incorporated the time needed for habitat functions to develop and the risk that restored habitats may never provide the same level of functions and services as the injured natural habitats. These models incorporate change in the level of resources or services provided by a restoration action over time, often included in models simply as a percentage of total ecosystem service provided by restored habitat (e.g., Lavaca Bay, NOAA 2000) However, HEA and REA models are only as strong as the data that support them. The restoration trajectories (often called "recovery trajectories" in HEA and REA applications) used in many previous HEA and REA models have frequently relied on data from only a handful of restoration projects or expert opinion (Strange et al. 2002). The meta-analyses presented in this theme section provide an opportunity to leverage larger, synthesized datasets to support the development of HEA and REA models for GOM coastal habitats that can more accurately estimate restoration project benefits over time. The REA model presented by Fricano et al. (2020) in this issue provides an example for how restoration trajectories derived through meta-analysis of regionally focused datasets can be used along with other regionally specific input parameters to develop more robust estimates of restoration benefits.

Many environmental mitigation scenarios require out-ofkind compensation for damages, such as restoring salt marsh to mitigate for injury to soft-sediment benthic habitat (English et al. 2009; Wickham et al. 1993). Another common scenario is a "benefits cascade," where a single restoration project benefits multiple trophic levels (Heinrich et al. 2014). For example, a marsh restoration project may be constructed to restore for fish that were killed by an oil spill. The marsh is an appropriate restoration option based on the assumption that the marsh will provide ecological services to the injured fish species. A common metric is needed when calculating compensatory restoration requirements in situations that involve outof-kind restoration or benefits cascades. In this issue, Cebrian et al. (2020) present a novel protocol for quantifying biomass at recruitment (for species with life history tables available) or productivity (for species without life history tables available) supported by different coastal habitats, which can be applied to help calculate out-of-kind restoration requirements.

Restoration trade-off scenarios have evolved from fairly straightforward trade-offs between similar habitats or resources to more complex applications. Prior approaches include the development of conversion factors based on productivity ratios for the same trophic level between habitat types (e.g., M/V Athos, French McCay et al. 2002), the development of equivalencies between trophic levels, and the application of simple food chain models using energy transfer efficiencies to scale across trophic levels (see, e.g., French McCay et al. 2002, 2003b; French McCay and Rowe 2003; Peterson et al. 2003, 2007). Recent advancements in ecosystem modeling approaches provide a means to integrate 
multiple components of the ecosystem, facilitating the consideration of different restoration scenarios (e.g., Ainsworth et al. 2018; de Mutsert et al. 2017). Robust estimates for the broadest possible array of various ecological functions of coastal habitats, such as those provided by the meta-analysis studies included in this theme section, can improve certainty in ecosystem model outputs by providing more robust values for model parameterization.

\section{Overview of the Theme Section}

This collection of papers provides insights into the quantification of benefits and the rate at which benefits develop for coastal habitat restoration projects in the northern GOM, USA region. The authors of the papers included in this collection conducted systematic reviews of the existing literature on coastal habitat restoration and utilization of coastal habitats by species impacted by the Deepwater Horizon oil spill. Metaanalysis was used to synthesize existing data related to marsh vegetation and soils; marsh resident fauna; and nekton abundance across marsh, oyster reef, submerged aquatic vegetation (SAV), and open-water non-vegetated bottom (NVB) habitats. The authors used the results of the meta-analyses to develop quantitative relationships describing the restoration of key structural characteristics and ecological functions and services over time in restored coastal habitats. Approaches are also presented to estimate the productivity of estuarine habitats, model the benefits associated with a hypothetical marsh restoration project, and quantify the benefits of removing derelict crab traps from estuaries. The synthesized datasets can be used to compare benefits associated with different types of restoration projects, serve as a reference for setting appropriate targets and performance criteria, and be applied to scale up the measured benefits of individual restoration projects to evaluate the longer-term, cumulative outcomes of restoration in the GOM. While this synthesis of existing data focuses specifically on the northern GOM, USA region, the results contribute to an overall better understanding of the ecological benefits of estuarine habitat restoration and can serve as a valuable reference for managers implementing restoration projects in other regions.

Ebbets et al. (2020) conducted a systematic literature review and meta-analysis to evaluate whether vegetation and soil parameters at fresh, brackish, and saline marsh sites restored using dredged sediment placement and thin layer sediment addition recover to levels found at paired reference sites. On average, belowground parameters (root biomass and soil organic matter) were 44 to $92 \%$ lower at restored sites younger than 15 years compared with the reference sites. Percent vegetation cover was $50 \%$ lower at restored sites compared with the reference sites over the first 5 years of restoration; in contrast, aboveground biomass was $25 \%$ higher at restored sites.
Mean recovery trajectories for belowground biomass and productivity, vegetation cover, and soil parameters indicated that mean values for restored sites reached reference site conditions within 30 years following restoration. However, the recovery curve for the 20th percentile of site data suggests slower recovery for some sites.

Baumann et al. (2020) examined recovery of the epifaunal gastropod periwinkle snail (Littorina irrorata) and a broad grouping of amphipod crustaceans (order Amphipoda) following salt marsh restoration in the northern GOM. Faunal recovery trajectories were developed using data from restored and reference marshes extracted from published, unpublished, and gray literature related to marsh structure and function following marsh creation, marsh rehabilitation, or experimental treatments that closely mimic marsh restoration. The results of the analysis indicate progressive recovery of periwinkle function to equivalence with reference by year six, while amphipods do not fully recover in the first 20 years following restoration. Although periwinkle function in terms of annual biomass addition reaches equivalence by year six, the development of a population structure characteristic of reference marshes would likely take longer because of the relatively long lifespan for this species.

Hollweg et al. (2020a) conducted a systematic literature search and meta-analysis to evaluate nekton densities across estuarine habitat types, including marsh, oyster reefs, SAV, and open-water NVB in the northern GOM. They corrected nekton densities for gear efficiencies to allow for comparisons across sites, studies, and habitats. Higher nekton densities were associated with structured estuarine habitats (i.e., marsh, oyster reefs, SAV) than with open-water NVB habitats. Marsh and SAV community assemblages were relatively similar to each other but different from those associated with open-water NVB and oyster habitats. Densities of recreationally and commercially important crustacean and fish species were highest in saline marshes, thus demonstrating the importance of these habitats in the northern GOM.

Hollweg et al. (2020b) conducted a meta-analysis of nekton densities measured at restored marsh sites in the GOM compared with the reference (i.e., natural) sites to describe general patterns of nekton recovery following restoration. Overall, total nekton densities at restored sites were generally lower than those at reference sites during the first decade following restoration. They found variations in restored versus reference densities when examining specific fish and crustacean taxa; densities of many crustacean taxa (e.g., penaeid shrimp Penaeidae spp., grass shrimp Palaemonidae spp.) and some fish taxa (e.g., gobies Gobiidae spp.) were generally lower at the restored sites, while restored densities of other crustacean taxa (e.g., portunid crabs Portunidae spp.) were similar to the reference densities. Nekton densities - and constituent crustacean densities - appeared to increase with the age of the restored sites and were comparable with densities 
at the reference sites by approximately year 13 , although the specific response varied for different species groups.

Cebrian et al. (2020) propose a method to standardize estimates of biomass at recruitment and nekton productivity that can be used to inform coastal habitat conservation or restoration actions in the northern GOM region, including efforts to restore coastal wetlands, SAV beds, and oyster reefs. The objective of their study was to develop a new protocol that, building upon existing methods, derives nekton biomass and productivity from density values. The method also allows for the quantification of the uncertainty around the derived biomass and productivity values, thereby allowing end users to obtain an accurate understanding of the value and variability of coastal ecosystems as habitat for nekton as well as developing effective strategies for the conservation and restoration of nekton coastal habitat.

Fricano et al. (2020) present a method for quantifying anticipated ecological benefits associated with marsh restoration projects, particularly marsh creation, in the northern GOM. Using salt marsh vegetation (percent cover, aboveground biomass, and belowground biomass), periwinkle snails, and amphipods as representative ecological components, they modeled anticipated ecological functioning over time and quantified total net project benefits for a hypothetical marsh creation project in Barataria Bay, Louisiana. They applied a rigorous approach to the development of input values, mining the scientific literature, Coastal Wetlands Planning, Protection and Restoration Act (CWPPRA) data, and other sources. They also demonstrate how model inputs can be varied to accommodate different marsh restoration techniques, salinity regimes, and geographic regions.

Arthur et al. (2020) present a method for determining the potential benefits of crab trap removal projects in northern GOM bays and estuaries. Recent stock assessments of blue crabs (Callinectes sapidus) in the GOM are discouraging, indicating the stock is in waning health (West et al. 2016). The authors conducted a synthesis of data made available by state natural resource management agencies and provide a novel approach to handling large uncertainties regarding trap loss rates. The outcomes of this analysis could serves as inputs for REA, including applying concepts of production forgone (French McCay et al. 2003a). An estimate of lost crab and finfish biomass is determined based upon rates of ghost fishing by derelict traps. The authors estimate that a 5 -year program would result in a benefit of $391,000 \mathrm{~kg}$ of crab and $300,000 \mathrm{~kg}$ of finfish not killed due to ghost fishing, for a combined benefit of $691,000 \mathrm{~kg}$ across the GOM. The approach used could be extended to estimate other measures of ecosystem performance, including reduced marine mammal entanglement, improved esthetics, and economic benefits to fishing communities. The article also brings attention to other persistent threats and stressors in estuaries such as marine debris. For certain ecosystems, habitat restoration alone may be less effective than approaches that also address other stressors to the system. This begs the question of how portfolios of restoration projects can be designed to address multiple stressors to a system.

\section{Key Take-Aways}

Coastal habitat restoration has been conducted for decades in the northern GOM region through existing programs such as the Coastal Wetlands Planning, Protection, and Restoration Act (CWPPRA) program, NOAA's Community-based Restoration Program, and the USFWS Coastal Program, with much more restoration planned or already underway as a result of the Deepwater Horizon settlements. However, many restoration projects are only monitored for a few years after construction, with most monitoring focused on meeting specific construction targets (e.g., marsh elevation, volume of constructed oyster reefs) and the development of structural habitat features (e.g., vegetation percent cover). The papers included in this theme section reveal the limited amount of long-term monitoring information currently available for coastal habitat restoration projects in the GOM (Table 1). Without more long-term monitoring data, natural variability makes it difficult to accurately predict restoration trajectories for some characteristics of restored marshes, particularly the extent to which slower developing functions might emerge over time (Callaway 2005; Zedler 2000). Larger, combined datasets, such as those derived in these papers, improve understanding of the ecological services and the rate of development of restored habitats.

While the papers in this volume draw on the best currently available data from the GOM region, combining data from numerous sites inherently introduces additional variability and requires large sample sizes. Increased long-term monitoring of individual projects combined with strategic re-sampling of older restoration projects could further improve the power of meta-analysis for developing restoration trajectories. Collecting longer-term monitoring data for a variety of different types of restoration projects and restoration projects with specific design features would help clarify which restoration actions are most effective at increasing the rate of development of desired functions. As the number of restoration projects with long-term monitoring data increases, it should become possible to distinguish differences between restoration techniques and shed more light on the drivers behind the differences in the rate of development of some habitat functions seen in individual studies. Additional data collection related to soil development, benthic community composition, and faunal habitat utilization would further improve understanding of the ecological services provided by restored habitats, the length of time required to achieve full functional equivalence with natural habitats, whether equivalence is ever achieved for 
Table 1 Summary of the number of restoration projects by age analyzed by the papers included in this theme section

\begin{tabular}{|c|c|c|c|c|c|c|c|c|c|c|}
\hline \multirow{3}{*}{$\begin{array}{l}\text { Project age } \\
\text { when } \\
\text { sampled }\end{array}$} & \multicolumn{10}{|c|}{ Number of coastal wetland restoration projects } \\
\hline & \multicolumn{6}{|c|}{ Ebbets et al. (2020) } & \multicolumn{2}{|c|}{ Baumann et al. (2020) } & \multicolumn{2}{|c|}{ Hollweg et al. (2020b) } \\
\hline & $\begin{array}{l}\text { Vegetation } \\
\text { percent } \\
\text { cover }\end{array}$ & $\begin{array}{l}\text { Aboveground } \\
\text { biomass }\end{array}$ & $\begin{array}{l}\text { Belowground } \\
\text { biomass }\end{array}$ & $\begin{array}{l}\text { Soil } \\
\text { organic } \\
\text { carbon }\end{array}$ & $\begin{array}{l}\text { Soil } \\
\text { P\&N }\end{array}$ & $\begin{array}{l}\text { Soil } \\
\text { total } \\
\text { nitrogen }\end{array}$ & $\begin{array}{l}\text { Periwinkle } \\
\text { density }\end{array}$ & $\begin{array}{l}\text { Amphipod } \\
\text { density }\end{array}$ & $\begin{array}{l}\text { Nekton density } \\
\text { (paired } \\
\text { analysis) }\end{array}$ & $\begin{array}{l}\text { Nekton density } \\
\text { (unpaired } \\
\text { analysis) }\end{array}$ \\
\hline $0-5$ & 31 & 14 & 12 & 20 & 9 & 2 & 42 & 6 & 7 & 13 \\
\hline $6-10$ & 12 & 6 & 9 & 14 & 4 & 2 & 9 & 4 & 3 & 3 \\
\hline $11-15$ & 3 & 1 & 3 & 8 & 1 & 0 & 2 & 2 & 2 & 2 \\
\hline $16-20$ & 0 & 2 & 3 & 7 & 2 & 2 & 0 & 0 & 0 & 0 \\
\hline $21-25$ & 1 & 1 & 1 & 2 & 0 & 0 & 0 & 2 & 0 & 0 \\
\hline $26-30$ & 0 & 0 & 0 & 0 & 0 & 0 & 0 & 0 & 1 & 0 \\
\hline$>30$ & 0 & 1 & 0 & 1 & 0 & 0 & 0 & 0 & 0 & 0 \\
\hline Total & 47 & 25 & 28 & 52 & 16 & 6 & 53 & 14 & 13 & 18 \\
\hline
\end{tabular}

all functions, and how to set appropriate performance expectations for restoration projects.

Acknowledgments The authors would like to thank Dr. Terill Hollweg and Dr. Matthew Baumann for providing the summary data on the number of restoration projects by age included in the theme section's metaanalysis papers. The views and conclusions expressed within this publication are those of the authors, supported by the National Oceanic and Atmospheric Administration, and do not necessarily represent the views of the other natural resource Trustees for the BP/Deepwater Horizon NRDA.

Open Access This article is licensed under a Creative Commons Attribution 4.0 International License, which permits use, sharing, adaptation, distribution and reproduction in any medium or format, as long as you give appropriate credit to the original author(s) and the source, provide a link to the Creative Commons licence, and indicate if changes were made. The images or other third party material in this article are included in the article's Creative Commons licence, unless indicated otherwise in a credit line to the material. If material is not included in the article's Creative Commons licence and your intended use is not permitted by statutory regulation or exceeds the permitted use, you will need to obtain permission directly from the copyright holder. To view a copy of this licence, visit http://creativecommons.org/licenses/by/4.0/.

\section{References}

Able, K.W. 2005. A re-examination of fish estuarine dependence: Evidence for connectivity between estuarine and ocean habitats. Estuarine, Coastal and Shelf Science 64 (1): 5-17. https://doi.org/ 10.1016/j.ecss.2005.02.002.

Able, K.W., T.M. Grothues, S.M. Hagan, M.E. Kimball, D.M. Nemerson, and G.L. Taghon. 2008. Long-term response of fishes and other fauna to restoration of former salt hay farms: Multiple measures of restoration success. Reviews in Fish Biology and Fisheries 18 (1): 65-97. https://doi.org/10.1007/s11160-007-90666.

Ainsworth, C.H., C.B. Paris, N. Perlin, L.N. Dornberger, W.F. Patterson III, E. Chancellor, S. Murawski, D. Hollander, K. Daly, I.C.
Romero, F. Coleman, and H. Perryman. 2018. Impacts of the Deepwater Horizon oil spill evaluated using an end-to-end ecosystem model. PLoS One 13 (1): e0190840. https://doi.org/10.1371/ journal.pone.0190840.

Allen, E.A., P.E. Fell, M.A. Peck, J.A. Gieg, C.R. Guthke, and M.D. Newkirk. 1994. Gut contents of common Mummichogs, Fundulus heteroclitus L., in a restored impounded marsh and in natural reference marshes. Estuaries 17 (2): 462-471.

Armitage, A.R., C.-K. Ho, E.N. Madrid, M.T. Bell, and A. Quigg. 2014. The influence of habitat construction technique on the ecological characteristics of a restored brackish marsh. Ecological Engineering 62: 33-42. https://doi.org/10.1016/j.ecoleng.2013.10.021.

Arthur, C., S. Friedman, J. Weaver, D. Van Nostrand, J. Reinhardt. 2020. Estimating the benefits of derelict crab trap removal in the Gulf of Mexico. Estuaries and Coasts. https://doi.org/10.1007/s12237-02000812-2.

Baillie, C.J., J.M. Fear, and F.J. Fodrie. 2015. Ecotone effects on seagrass and saltmarsh habitat use by juvenile nekton in a temperate estuary. Estuaries and Coasts 38 (5): 1414-1430. https://doi.org/10.1007/ s12237-014-9898-y.

Baltz, D.M., C. Rakocinski, and J.W. Fleeger. 1993. Microhabitat use by marsh-edge fishes in a Louisiana estuary. Environmental Biology of Fishes 36 (2): 109-126. https://doi.org/10.1007/bf00002790.

Baumann, M.S., G.F. Fricano, K. Fedeli, C.E. Schlemme, M.C. Christman, and M.V. Carle. 2020. Recovery of salt marsh invertebrates following habitat restoration: Implications for marsh restoration in the Northern Gulf of Mexico. Estuaries and Coasts. https:// doi.org/10.1007/s12237-018-0469-5.

Beck, M.W., and M. Odaya. 2001. Ecoregional planning in marine environments: Identifying priority sites for conservation in the northern Gulf of Mexico. Aquatic Conservation: Marine and Freshwater Ecosystems 11 (4): 235-242. https://doi.org/10.1002/aqc.449.

Beck, M.W., K.L. Heck, K.W. Able, D.L. Childers, D.B. Eggleston, B.M. Gillanders, B.S. Halpern, C.G. Hays, K. Hoshino, T.J. Minello, R.J. Orth, P.F. Sheridan, and M.P. Weinstein. 2001. The identification, conservation, and management of estuarine and marine nurseries for fish and invertebrates. BioScience 51 (8): 633-641.

Bell, S.S., A. Tewfik, M.O. Hall, and M.S. Fonseca. 2008. Evaluation of seagrass planting and monitoring techniques: Implications for assessing restoration success and habitat equivalency. Restoration Ecology 16 (3): 407-416. https://doi.org/10.1111/j.1526-100X. 2007.00308.x. 
Bell, S.S., M.L. Middlebrooks, and M.O. Hall. 2014. The value of longterm assessment of restoration: Support from a seagrass investigation. Restoration Ecology 22 (3): 304-310. https://doi.org/10.1111/ rec. 12087.

Beseres Pollack, J., A. Cleveland, T.A. Palmer, A.S. Reisinger, and P.A. Montagna. 2012. A restoration suitability index model for the eastern oyster (Crassostrea virginica) in the Mission-Aransas Estuary, TX, USA. PLoS One 7 (7): e40839. https://doi.org/10.1371/journal. pone.0040839.

Blandon, A., and P.S.E. zu Ermgassen. 2014. Quantitative estimate of commercial fish enhancement by seagrass habitat in southern Australia. Estuarine, Coastal and Shelf Science 141: 1-8. https:// doi.org/10.1016/j.ecss.2014.01.009.

Boesch, D.F., and R.E. Turner. 1984. Dependence of fishery species on salt marshes: The role of food and refuge. Estuaries 7 (4): 460-468.

Bologna, P.A.X., and M.S. Sinnema. 2012. Restoration of seagrass habitat in New Jersey, United States. Journal of Coastal Research 278: 99-104. https://doi.org/10.2112/jcoastres-d-10-00062.1.

Breitburg, D.L., M.A. Palmer, and T. Loher. 1995. Larval distributions and the spatial patterns of settlement of an oyster reef fish: Responses to flow and structure. Marine Ecology Progress Series 125: 45-60

Callaway, J. C. 2005. The challenge of restoring functioning salt marsh ecosystem. Journal of Coastal Research Special Issue No. 40, Coastal Restoration: Where have we been, where are we now, and where should we be going? (WINTER 2005): 24-36.

Cebrian, J., H. Liu, M. Christman, T. Hollweg, D. French McCay, R. Balouskus, C. McManus, H. Ballestero, J. White, S. Friedman, and K. Benson. 2020. Standardizing estimates of biomass at recruitment and productivity for fin- and shellfish in coastal habitats. Esuaries and Coasts. https://doi.org/10.1007/s12237-019-00691-2.

Chambers, L.G., S.A. Gaspar, C.J. Pilato, H.E. Steinmuller, K.J. McCarthy, P.E. Sacks, and L.J. Walters. 2017. How well do restored intertidal oyster reefs support key biogeochemical properties in a coastal lagoon? Estuaries and Coasts 41 (3): 784-799. https://doi. org/10.1007/s12237-017-0311-5.

Chowdhury, M.S.N., M.S. Hossain, T. Ysebaert, and A.C. Smaal. 2020. Do oyster breakwater reefs facilitate benthic and fish fauna in a dynamic subtropical environment? Ecological Engineering 142: 105635. https://doi.org/10.1016/j.ecoleng.2019.105635.

Cole, C.A. 2002. The assessment of herbaceous plant cover in wetlands as an indicator of function. Ecological Indicators 2 (3): 287-293. https://doi.org/10.1016/s1470-160x(02)00064-x.

Craft, C., and J. Sacco. 2003. Long-term succession of benthic infauna communities on constructed Spartina alterniflora marshes. Marine Ecology Progress Series 257: 45-58.

Craft, C., J. Reader, J.N. Sacco, and S.W. Broome. 1999. Twenty-five years of ecosystem development of constructed Spartina alterniflora (Loisel) marshes. Ecological Applications 9 (4): 1405-1419. https:// doi.org/10.1890/1051-0761(1999)009[1405:tfyoed]2.0.co;2.

Craft, C., S. Broome, and C. Campbell. 2002. Fifteen years of vegetation and soil development after brackish-water marsh creation. Restoration Ecology 10 (2): 248-258.

Craft, C., P. Megonigal, S. Broome, J. Stevenson, R. Freese, J. Cornell, L. Zheng, and J. Sacco. 2003. The pace of ecosystem development of constructed Spartina alterniflora marshes. Ecological Applications 13 (5): 1417-1432.

Cui, B.S., Q.C. Yang, Z.F. Yang, and K.J. Zhang. 2009. Evaluating the ecological performance of wetland restoration in the Yellow River Delta, China. Ecological Engineering 35 (7): 1090-1103.

Cunha, A.H., N.N. Marbá, M.M. van Katwijk, C. Pickerell, M. Henriques, G. Bernard, M.A. Ferreira, S. Garcia, J.M. Garmendia, and P. Manent. 2012. Changing paradigms in Seagrass restoration. Restoration Ecology 20 (4): 427-430. https://doi.org/10.1111/j. 1526-100X.2012.00878.x. de Mutsert, K., K. Lewis, S. Milroy, J. Buszowski, and Jeroen Steenbeek. 2017. Using ecosystem modeling to evaluate trade-offs in coastal management: Effects of large-scale river diversions on fish and fisheries. Ecological Modelling 360: 14-26. https://doi.org/10.1016/j. ecolmodel.2017.06.029.

Deegan, L.A. 1993. Nutrient and energy transport between estuaries and coastal marine ecosystems by fish migration. Canadian Journal of Fisheries and Aquatic Sciences 50 (1): 74-79.

Deegan, L.A., J.E. Hughes, and R.A. Rountree. 2002. Salt marsh ecosystem support of marine transient species. In Concepts and controversies in tidal marsh ecology, ed. M.P. Weinstein and D.A. Kreeger, 333-365. Dordrecht: Springer.

Deepwater Horizon Natural Resource Damage Assessment Trustees. 2016. Deepwater Horizon Oil Spill: Final Programmatic Damage Assessment Restoration Plan/ Programmatic Environmental Impact Statement. Accessed 11 Dec 2019 https://www. gulfspillrestoration.noaa.gov/restoration-planning/gulf-plan.

Desvousges, W.H., N. Gard, H.J. Michael, and A.D. Chance. 2018. Habitat and resource equivalency analysis: A critical Assessment. Ecological Economics 143: 74-89. https://doi.org/10.1016/j. ecolecon.2017.07.003.

Dillon, K.S., M.S. Peterson, and C.A. May. 2015. Functional equivalence of constructed and natural intertidal eastern oyster reef habitats in a northern Gulf of Mexico estuary. Marine Ecology Progress Series 528: 187-203. https://doi.org/10.3354/meps11269.

Dionne, M., F.T. Short, and D.M. Burdick. 1999. Fish utilization of restored, created and reference salt-marsh habitat in the Gulf of Maine. American Fisheries Society Symposium 22: 384-404.

Ebbets, A.L., D.R. Lane, P. Dixon, T.A. Hollweg, M.T. Huisenga, and J. Gurevitch. 2020. Using meta-analysis to develop evidence-based recovery trajectories of vegetation and soils in restored wetlands in the Northern Gulf of Mexico. Estuaries and Coasts. https://oi.org/ 10.1007/s12237-019-00536-y.

Edwards, K.R., and C.E. Proffitt. 2003. Comparison of wetland structural characteristics between created and natural salt marshes in Southwest Louisiana, USA. Wetlands 23 (2): 344-356.

English, E. P., C. H. Peterson, and C. M. Voss. 2009. Ecology and economics of compensatory restoration. https://www.researchgate. net/profile/Eric English2/publication/265632816 Ecology and Economics_of_Compensatory_Restoration/links/ 5b57873b458515c4b2435556/Ecology-and-Economics-ofCompensatory-Restoration.pdf. Accessed 11 Dec 2019.

Fonseca, M.S., W.J. Kenworthy, D.R. Colby, K.A. Rittmaster, and G.W. Thayer. 1990. Comparisons of fauna among natural and transplanted eelgrass Zostera marina meadows: Criteria for mitigation. Marine Ecology Progress Series 65: 1990.

Fonseca, M.S., W.J. Kenworthy, and F.X. Courtney. 1996a. Development of planted seagrass beds in Tampa Bay, Florida, USA. I. Plant components. Marine Ecology Progress Series 132: $127-139$.

Fonseca, M.S., D.L. Meyer, and M.O. Hall. 1996b. Development of planted seagrass beds in Tampa Bay, Florida, USA. II. Faunal components. Marine Ecology Progress Series 132: 141-156.

Fonseca, M.S., B.E. Julius, and W.J. Kenworthy. 2000. Integrating biology and economics in seagrass restoration: How much is enough and why? Ecological Engineering 15 (3-4): 227-237.

Frederick, P., N. Vitale, B. Pine, J. Seavey, and L. Sturmer. 2016. Reversing a rapid decline in oyster reefs: Effects of durable substrate on oyster populations, elevations, and aquatic bird community composition. Journal of Shellfish Research 35 (2): 359-367. https://doi. org/10.2983/035.035.0210.

French McCay, D., and J.J. Rowe. 2003. Habitat restoration as mitigation for lost production at multiple trophic levels. Marine Ecology Progress Series 264: 233-247.

French McCay, D., P. Peterson, and M. Donlan. 2002. Restoration scaling of benthic, aquatic, and bird injuries to oyster reef and marsh 
restoration projects. https://pub-data.diver.orr.noaa.gov/adminrecord $/ 6404 /$ French $\% 20 \mathrm{McCay} \% 20 \mathrm{et} \% 20$ al\%202002.pdf. Accessed 11 Dec 2019.

French McCay, D., M. Gibson, and J. Cobb. 2003a. Scaling restoration of American lobsters: Combined demographic and discounting model for an exploited species. Marine Ecology Progress Series 264: 177196. https://doi.org/10.3354/meps264177.

French McCay, D.P., C.H. Peterson, J.T. DeAlteris, and J. Catena. 2003b. Restoration that targets function as opposed to structure: Replacing lost bivalve production and filtration. Marine Ecology Progress Series 264: 197-212.

Fricano, G.F., M.S. Baumann, K. Fedeli, C.E. Schlemme, M.V. Carle, and M. Landry. 2020. Modeling coastal marsh restoration benefits in the Northern Gulf of Mexico. Estuaries and Coasts. https://doi.org/ 10.1007/s12237-020-00706-3.

Geraldi, N.R., S.P. Powers, K.L. Heck, and J. Cebrian. 2009. Can habitat restoration be redundant? Response of mobile fishes and crustaceans to oyster reef restoration in marsh tidal creeks. Marine Ecology Progress Series 389: 171-180. https://doi.org/10.3354/meps08224.

Gilby, B.L., A.D. Olds, C.J. Henderson, N.L. Ortodossi, R.M. Connolly, T.A. Schlacher, and J. Grabowski. 2019. Seascape context modifies how fish respond to restored oyster reef structures. ICES Journal of Marine Science 76 (4): 1131-1139. https://doi.org/10.1093/icesjms/ fsz019.

Glancy, T.P., T.K. Frazer, C.E. Cichra, and W.J. Lindberg. 2003. Comparative patterns of occupancy by decapod crustaceans in seagrass, oyster, and marsh-edge habitats in a Northeast Gulf of Mexico estuary. Estuaries 26 (5): 1291-1301.

Golden, R.R., K.E. Busch, L.P. Karrh, T.A. Parham, M.J. Lewandowski, and M.D. Naylor. 2010. Large-scale Zostera marina (eelgrass) restoration in Chesapeake Bay, Maryland, USA. Part II: A comparison of restoration methods in the Patuxent and Potomac Rivers. Restoration Ecology 18 (4): 501-513. https://doi.org/10.1111/j. 1526-100X.2010.00691.x.

Grabowski, J., A.R. Hughes, D.L. Kimbro, and M.A. Dolan. 2005. How habitat setting influences restored oyster reef communities. Ecology 86 (7): 1926-1935.

Gulf Coast Ecosystem Restoration Council. 2016. Comprehensive plan update 2016: Restoring the Gulf Coast's ecosystem and economy. https://www.restorethegulf.gov/sites/default/files/CO-PL 20161208 CompPlanUpdate English.pdf. Accessed 11 Dec 2019.

Hadley, N.H., M. Hodges, D.H. Wilber, and L.D. Coen. 2010. Evaluating intertidal oyster reef development in South Carolina using associated faunal indicators. Restoration Ecology 18 (5): 691-701. https:// doi.org/10.1111/j.1526-100X.2008.00502.x.

Hanke, M.H., M.H. Posey, and T.D. Alphin. 2017. The influence of habitat characteristics on intertidal oyster Crassostrea virginica populations. Marine Ecology Progress Series 571: 121-138. https://doi. org/10.3354/meps 12094 .

Harwell, H.D., M.H. Posey, and T.D. Alphin. 2011. Landscape aspects of oyster reefs: Effects of fragmentation on habitat utilization. Journal of Experimental Marine Biology and Ecology 409 (1-2): 30-41. https://doi.org/10.1016/j.jembe.2011.07.036.

Havens, K.J., L.M. Varnell, and B.D. Watts. 2002. Maturation of a constructed tidal marsh relative to two natural reference tidal marshes over 12 years. Ecological Engineering 18 (3): 305-315. https://doi. org/10.1016/s0925-8574(01)00089-1.

Heinrich, K.K., M.R. Whiles, and C. Roy. 2014. Cascading ecological responses to an in-stream restoration project in a Midwestern River. Restoration Ecology 22 (1): 72-80. https://doi.org/10.1111/rec. 12026.

Hollweg, T.A., M.C. Christman, J. Cebrian, B.P. Wallace, S.L. Friedman, H.R. Ballestero, M.T. Huisenga, and K.G. Benson. 2020a. Metaanalysis of nekton utilization of coastal habitats in the northern Gulf of Mexico. Estuaries and Coasts. https://doi.org/10.1007/s12237019-00633-y.
Hollweg, T.A., M.C. Christman, J. Lipton, B.P. Wallace, M.T. Huisenga, D. Lane, and K.G. Benson. 2020b. Meta-analysis of nekton recovery following marsh restoration in the northern Gulf of Mexico. Estuaries and Coasts. https://doi.org/10.1007/s12237-019-00630-1.

Humphries, A.T., and M.K. La Peyre. 2015. Oyster reef restoration supports increased nekton biomass and potential commercial fishery value. PeerJ 3: e1111. https://doi.org/10.7717/peerj.1111.

Irlandi, E.A., and M.K. Crawford. 1997. Habitat linkages: The effect of intertidal saltmarshes and adjacent subtidal habitats on abundance, movement, and growth of an estuarine fish. Oecologia 110 (2): 222 230. https://doi.org/10.1007/s004420050154.

Jahnke, M., I.A. Serra, G. Bernard, and G. Procaccini. 2015. The importance of genetic make-up in seagrass restoration: A case study of the seagrass Zostera noltei. Marine Ecology Progress Series 532: 111122. https://doi.org/10.3354/meps11355.

James-Pirri, M.J., K.B. Raposa, and J.G. Catena. 2001. Diet composition of Mummichogs, Fundulus heteroclitus, from restoring and unrestricted regions of a New England (U.S.A.) salt marsh. Estuarine. Coastal and Shelf Science 53 (2): 205-213. https://doi.org/10.1006/ ecss.2001.0807.

Jänes, H., P.I. Macreadie, P.S.E. Zu Ermgassen, J.R. Gair, S. Treby, S. Reeves, E. Nicholson, D. Ierodiaconou, and P. Carnell. 2020. Quantifying fisheries enhancement from coastal vegetated ecosystems. Ecosystem Services 43: 101105. https://doi.org/10.1016/j. ecoser.2020.101105.

Jivoff, P.R., and K.W. Able. 2003. Evaluating salt marsh restoration in Delaware Bay: The response of blue crabs, Callinectes sapidus, at former salt hay farms. Estuaries 26 (3): 709-719.

Karp, M.A., R.D. Seitz, and M.C. Fabrizio. 2018. Faunal communities on restored oyster reefs: Effects of habitat complexity and environmental conditions. Marine Ecology Progress Series 590: 35-51. https:// doi.org/10.3354/meps 12470 .

Keller, D.A., R.K. Gittman, M.C. Brodeur, M.D. Kenworthy, J.T. Ridge, L.A. Yeager, A.B. Rodriguez, and F.J. Fodrie. 2019. Salt marsh shoreline geomorphology influences the success of restored oyster reefs and use by associated fauna. Restoration Ecology 27 (6): 1429-1441. https://doi.org/10.1111/rec.12992.

Kenworthy, W. J., M. S. Fonseca, J. Homziak, and G. W. Thayer. 1980. Development of a transplanted seagrass (Zostera marina L.) meadow in Back Sound, Carteret County, North Carolina. In Proceedings of the Seventh Annual Conference on the Restoration and Creation of Wetlands, 175-193. Tampa, FL.

Kenworthy, W.J., M.O. Hall, K.K. Hammerstrom, M. Merello, and A. Schwartzschild. 2018. Restoration of tropical seagrass beds using wild bird fertilization and sediment regrading. Ecological Engineering 112: 72-81. https://doi.org/10.1016/j.ecoleng.2017. 12.008 .

Kirsch, K. D., K. A. Barry, M. S. Fonseca, P. E. Whitfield, S. R. Meehan, W. J. Kenworthy, and B. E. Julius. 2005. The Mini-312 ProgramAn expedited damage assessment and restoration process for seagrasses in the Florida Keys National Marine Sanctuary. Journal of Coastal Research Special Issue No. 40. Coastal Restoration: Where have we been, where are we now, and where should we be going? (WINTER 2005): 109-119.

Konisky, R.A., D.M. Burdick, M. Dionne, and H.A. Neckles. 2006. A regional assessment of salt marsh restoration and monitoring in the Gulf of Maine. Restoration Ecology 14 (4): 516-525. https://doi. org/10.1111/j.1526-100X.2006.00163.x.

La Peyre, M.K., A.T. Humphries, S.M. Casas, and J.F. La Peyre. 2014. Temporal variation in development of ecosystem services from oyster reef restoration. Ecological Engineering 63: 34-44. https://doi. org/10.1016/j.ecoleng.2013.12.001.

Larkin, D.J., S.P. Madon, J.M. West, and J.B. Zedler. 2008. Topographic heterogeneity influences fish use of an experimentally restored tidal marsh. Ecological Applications 18 (2): 483-496. 
Lechêne, A., P. Boët, P. Laffaille, and J. Lobry. 2018. Nekton communities of tidally restored marshes: A whole-estuary approach. Estuarine, Coastal and Shelf Science 207: 368-382. https://doi. org/10.1016/j.ecss.2017.08.038.

Lechene, A., J. Lobry, P. Boet, and P. Laffaille. 2018. Change in fish functional diversity and assembly rules in the course of tidal marsh restoration. PLoS One 13 (12): e0209025. https://doi.org/10.1371/ journal.pone.0209025.

Lefcheck, J.S., B.B. Hughes, A.J. Johnson, B.W. Pfirrmann, D.B. Rasher, A.R. Smyth, B.L. Williams, M.W. Beck, and R.J. Orth. 2019. Are coastal habitats important nurseries? A meta-analysis. Conservation Letters 12: e12645. https://doi.org/10.1111/conl.12645.

Levin, P.S., and G.W. Stunz. 2005. Habitat triage for exploited fishes: Can we identify essential "essential fish habitat?". Estuarine, Coastal and Shelf Science 64 (1): 70-78. https://doi.org/10.1016/j. ecss.2005.02.007.

Levin, L.A., D. Talley, and G. Thayer. 1996. Succession of macrobenthos in a created salt marsh. Marine Ecology Progress Series 141: 67-82.

Lipton, J., E. Özdemiroğlu, K. LeJeune, and J. Peers. 2018. Resource equivalency methods in the European Union: A 'toolkit' for calculating environmental liability. In Equivalency methods for environmental liability, ed. Lipton J., Özdemiroğlu E., Chapman D., Peers J., 21-42. Dordrecht: Springer.

Llewellyn, C., and M. La Peyre. 2011. Evaluating ecological equivalence of created marshes: Comparing structural indicators with stable isotope indicators of blue crab trophic support. Esuaries and Coasts 34 (1): 172-184. https://doi.org/10.1007/sl2237-010-9297-y.

Luckenbach, M., L. Wainger, D. Weller, S. Bell, M. Fonseca, K. Heck, H. Neckles, M. Smart, and C. Pickerell. 2011. Evaluation of the effectiveness of SAV restoration approaches in the Chesapeake Bay. Chesapeake Bay Program's Scientific and Technical Advisory Committee (STAC). 11-03.

Madrid, E.N., A. Quigg, and A.R. Armitage. 2012. Marsh construction techniques influence net plant carbon capture by emergent and submerged vegetation in a brackish marsh in the northwestern Gulf of Mexico. Ecological Engineering 42: 54-63.

McCay, D.P.F., C.H. Peterson, J.T. Dealteris, and J. Catena. 2003. Restoration that targets function as opposed to structure : Replacing lost bivalve production and filtration. Marine Ecology Progress Series 264: 197-212.

McGlathery, K.J., L.K. Reynolds, L.W. Cole, R.J. Orth, S.R. Marion, and A. Schwarzschild. 2012. Recovery trajectories during state change from bare sediment to eelgrass dominance. Marine Ecology Progress Series 448: 209-221. https://doi.org/10.3354/meps09574.

McSkimming, C., S.D. Connell, B.D. Russell, and J.E. Tanner. 2016. Habitat restoration: Early signs and extent of faunal recovery relative to seagrass recovery. Estuarine, Coastal and Shelf Science 171: 5157. https://doi.org/10.1016/j.ecss.2016.01.028.

Meli, P., J.M. Rey Benayas, P. Balvanera, and M. Martinez Ramos. 2014. Restoration enhances wetland biodiversity and ecosystem service supply, but results are context-dependent: A meta-analysis. PLoS One 9 (4): e93507. https://doi.org/10.1371/journal.pone.0093507.

Meyer, D.L., and E.C. Townsend. 2000. Faunal utilization of created intertidal eastern oyster (Crassostrea virginica) reefs in the southeastern United States. Estuaries 23 (1): 34-45.

Meynecke, J.O., S.Y. Lee, and N.C. Duke. 2008. Linking spatial metrics and fish catch reveals the importance of coastal wetland connectivity to inshore fisheries in Queensland, Australia. Biological Conservation 141 (4): 981-996. https://doi.org/10.1016/j.biocon. 2008.01.018

Miller, M.J., and K.W. Able. 2002. Movements and growth of tagged young-of-the-year Atlantic croaker (Micropogonias undulatus L.) in restored and reference marsh creeks in Delaware Bay, USA. Journal of Experimental Marine Biology and Ecology 267 (1): 15-33.

Minello, T.J. 2000. Temporal development of salt marsh value for nekton and epifauna: Utilization of dredged material marshes in Galveston
Bay, Texas, USA. Wetlands Ecology and Management 8 (5): 327 341.

Minello, T.J., and L.P. Rozas. 2002. Nekton in Gulf Coast wetlands: Fine-scale distributions, landscape patterns, and restoration implications. Ecological Applications 12 (2): 441-455.

Minello, T.J., and J.W. Webb. 1997. Use of natural and created Spartina alterniflora salt marshes by fishery species and other aquatic fauna in Galveston Bay, Texas, USA. Marine Ecology Progress Series 151: $165-179$.

Minello, T.J., and R.J. Zimmerman. 1992. Utilization of natural and transplanted Texas salt marshes by fish and decapod crustaceans. Marine Ecology Progress Series 90: 273-285. https://doi.org/10. 3354/meps090273.

Minello, T.J., R.J. ZImmerman, and R. Medina. 1994. The importance of edge for natant macrofauna in a created salt marsh. Wetlands 14 (3): 184-198.

Moreno-Mateos, D., M.E. Power, F.A. Comin, and R. Yockteng. 2012. Structural and functional loss in restored wetland ecosystems. PLoS Biology 10 (1): e1001247. https://doi.org/10.1371/journal.pbio. 1001247.

Morgan, P.A., and F.T. Short. 2002. Using functional trajectories to track constructed salt marsh development in the Great Bay estuary, Maine/New Hampshire, U.S.a. Restoration Ecology 10 (3): 461473.

Moy, L.D., and L.A. Levin. 1991. Are Spartina marshes a replaceable resource - A functional-approach to evaluation of marsh creation efforts. Estuaries 14 (1): 1-16. https://doi.org/10.2307/1351977.

National Oceanic and Atmospheric Administration, Damage Assessment and Restoration Program. 1995. Habitat equivalency analysis: An overview. https://casedocuments.darrp.noaa.gov/northwest/cbay/ pdf/cbhy-a.pdf. Accessed 11 Dec 2019.

National Oceanic and Atmospheric Administration, Damage Assessment and Restoration Program. 1997. Scaling compensatory restoration actions: Guidance Document for natural resource damage assessment under the Oil Pollution Act of 1990. http://www.losco.state. la.us/pdf docs/NOAA NRDA Guidance Scaling 1997.pdf. Accessed 11 Dec 2019.

National Oceanic and Atmospheric Administration, Damage Assessment and Restoration Program. 2000. Lavaca Bay injury quantification and restoration determination. https://casedocuments.darrp.noaa. $\mathrm{gov} / \mathrm{s}$ o u the a s t/ 1 a va c a / p d f/L a v a a LavacaBayInjuryQuantificationandRestorationDetermination 1931.pdf. Accessed 11 Dec 2019.

Nelson, J., R. Wilson, F. Coleman, C. Koenig, D. DeVries, C. Gardner, and J. Chanton. 2011. Flux by fin: Fish-mediated carbon and nutrient flux in the northeastern Gulf of Mexico. Marine Biology 159 (2): 365-372. https://doi.org/10.1007/s00227-011-1814-4.

Nemerson, D.M., and K.W. Able. 2005. Juvenile sciaenid fishes respond favorably to Delaware Bay marsh restoration. Ecological Engineering 25 (3): 260-274.

Odum, E.P. 1980. The status of three ecosystem-level hypotheses regarding salt marsh estuaries: Tidal subsidy, outwelling, and detritusbased food chains. In Estuarine perspectives, ed. V.S. Kennedy, 485-495. Academic Press.

Orth, R.J., S.R. Marion, K.A. Moore, and D.J. Wilcox. 2009. Eelgrass (Zostera marina L.) in the Chesapeake Bay region of Mid-Atlantic Coast of the USA: Challenges in conservation and restoration. Estuaries and Coasts 33 (1): 139-150. https://doi.org/10.1007/ s12237-009-9234-0.

Orth, R.J., M.R. Williams, S.R. Marion, D.J. Wilcox, T.J.B. Carruthers, K.A. Moore, W.M. Kemp, W.C. Dennison, N. Rybicki, P. Bergstrom, and R.A. Batiuk. 2010. Long-term trends in submersed aquatic vegetation (SAV) in Chesapeake Bay, USA, related to water quality. Estuaries and Coasts 33 (5): 1144-1163. https://doi.org/10. 1007/s12237-010-9311-4. 
Peterson, G.W., and R.E. Turner. 1994. The value of salt marsh edge vs interior as a habitat for fish and decapod crustaceans in a Louisiana tidal marsh. Estuaries 17 (1): 235-262.

Peterson, C.H., J.H. Grabowski, and S.P. Powers. 2003. Estimated enhancement of fish production resulting from restoring oyster reef habitat: Quantitative valuation. Marine Ecology Progress Series 264: 249-264.

Peterson, C. H., M. Wong, M. F. Piehler, J. H. Grabowski, R. R. Twilley, and M. S. Fonseca. 2007. Estuarine habitat productivity ratios at multiple trophic levels. Final Report to NOAA Office of Response and Restoration, Assessment and Restoration Division.

Powell, G.V.N., J.W. Fourqurean, W.J. Kenworth, and J.C. Zieman. 1991. Bird colonies cause seagrass enrichment in a subtropical estuary: Observational and experimental evidence. Estuarine Coastal and Shelf Science 32 (6): 567-579.

Powers, S.P., C.H. Peterson, J.H. Grabowski, and H.S. Lenihan. 2009. Success of constructed oyster reefs in no-harvest sanctuaries: Implications for restoration. Marine Ecology Progress Series 389: 159-170. https://doi.org/10.3354/meps08164.

Raposa, K.B., and D.M. Talley. 2012. A meta-analysis of nekton responses to restoration of tide-restricted New England salt marshes. In Tidal marsh restoration: A synthesis of science and management, ed. C.T. Roman and D.M. Burdick, 97-118. Washington: Island Press.

Reynolds, L.K., K.J. McGlathery, and M. Waycott. 2012. Genetic diversity enhances restoration success by augmenting ecosystem services. PLoS One 7 (6): e38397. https://doi.org/10.1371/journal. pone.0038397.

Rezek, R.J., B. Lebreton, E.B. Roark, T.A. Palmer, and J.B. Pollack. 2017. How does a restored oyster reef develop? An assessment based on stable isotopes and community metrics. Marine Biology 164. https://doi.org/10.1007/s00227-017-3084-2.

Roman, C.T., K.B. Raposa, S.C. Adamowicz, M.J. James-Pirri, and J.G. Catena. 2002. Quantifying vegetation and nekton response to tidal restoration of a New England salt marsh. Restoration Ecology 10 (3): $450-460$.

Rountree, R.A., and K.W. Able. 2006. Spatial and temporal habitat use patterns for salt marsh nekton: Implications for ecological functions. Aquatic Ecology 41 (1): 25-45. https://doi.org/10.1007/s10452006-9052-4.

Rozas, L.P., and T.J. Minello. 1998. Nekton use of salt marsh, seagrass, and nonvegetated habitats in a South Texas (USA) estuary. Bulletin of Marine Science 63: 481-501.

Rozas, L.P., and T.J. Minello. 2009. Using nekton growth as a metric for assessing habitat restoration by marsh terracing. Marine Ecology Progress Series 394: 179-193.

Rozas, L.P., and R.J. Zimmerman. 2000. Small-scale patterns of nekton use among marsh and adjacent shallow nonvegetated areas of the Galveston Bay Estuary, Texas (USA). Marine Ecology Progress Series 193: 217-239.

Rutledge, K.M., T. Alphin, and M. Posey. 2018. Fish utilization of created vs. natural oyster reefs (Crassostrea virginica). Estuaries and Coasts 41 (8): 2426-2432. https://doi.org/10.1007/s12237-0180433-4.

Scapin, L., M. Zucchetta, C. Facca, A. Sfriso, and P. Franzoi. 2016. Using fish assemblage to identify success criteria for seagrass habitat restoration. Web Ecology 16 (1): 33-36. https://doi.org/10.5194/we-1633-2016.

Schulte, D.M., R.P. Burke, and R.N. Lipcius. 2009. Unprecedented restoration of a native oyster Metapopulation. Science 325 (5944): $1124-1127$

Scyphers, S.B., S.P. Powers, K.L. Heck Jr., and D. Byron. 2011. Oyster reefs as natural breakwaters mitigate shoreline loss and facilitate fisheries. PLoS One 6 (8): e22396. https://doi.org/10.1371/journal. pone.0022396.
Shelamoff, V., C. Layton, M. Tatsumi, M.J. Cameron, J.T. Wright, and C.R. Johnson. 2019. Ecosystem engineering by a canopy-forming kelp facilitates the recruitment of native oysters. Restoration Ecology 27 (6): 1442-1451. https://doi.org/10.1111/rec.13019.

Sheridan, P. 2004. Comparison of restored and natural seagrass beds near Corpus Christi, Texas. Estuaries 27 (5): 781-792.

Sheridan, P., C. Henderson, and G. McMahan. 2003. Fauna of natural seagrass and transplanted Halodule wrightii (Shoalgrass) beds in Galveston Bay, Texas. Restoration Ecology 11 (2): 139-154.

Silliman, B.R., E. Schrack, Q. He, R. Cope, A. Santoni, T. van der Heide, R. Jacobi, M. Jacobi, and J. van de Koppel. 2015. Facilitation shifts paradigms and can amplify coastal restoration efforts. Proceedings of the National Academy of Sciences of the United States of America 112 (46): 14295-14300. https://doi.org/10.1073/pnas.1515297112.

Simenstad, C.A., and R.M. Thom. 1996. Functional equivalency trajectories of the restored Gog-Le-Hi-Te Estuarine wetland. Ecological Applications 6 (1): 38-56.

Staszak, L.A., and A.R. Armitage. 2013. Evaluating salt marsh restoration success with an index of ecosystem integrity. Journal of Coastal Research 29: 410-418.

Strange, E., H. Galbraith, S. Bickel, D. Mills, D. Beltman, and J. Lipton. 2002. Determining ecological equivalence in service-to-service scaling of salt marsh restoration. Environmental Management 29 (2): 290-300. https://doi.org/10.1007/s00267-001-0019-X.

Streever, W.J. 2000. Spartina alterniflora marshes on dredged material: A critical review of the ongoing debate over success. Wetland Ecology and Management 8 (5): 295-316.

Stunz, G.W., T.J. Minello, and P.S. Levin. 2002. A comparison of early juvenile red drum densities among various habitat types in Galveston Bay, Texas. Estuaries 25 (1): 76-85.

Stunz, G.W., T.J. Minello, and L.P. Rozas. 2010. Relative value of oyster reef as habitat for estuarine nekton in Galveston Bay, Texas. Marine Ecology Progress Series 406: 147-159. https://doi.org/10.3354/ meps08556.

Swamy, V., P.E. Fell, M. Body, M.B. Keaney, M.K. Nyaku, E.C. Mcllvain, and A.L. Keen. 2002. Macroinvertebrate and fish populations in a restored impounded salt marsh 21 years after the reestablishment of tidal flooding. Environmental Management 29 (4): 516-530.

Teo, S.L.H., and K.W. Able. 2003a. Growth and production of the mummichog (Fundulus heteroclitus) in a restored salt marsh. Estuaries 26 (1): 51-63.

Teo, S.L.H., and K.W. Able. 2003b. Habitat use and movement of the mummichog (Fundulus heteroclitus) in a restored salt marsh. Estuaries 26 (3): 720-730.

Thayer, G. W., T. A. McTigue, R. J. Bellmer, F. M. Burrows, D. H. Merkey, A. D. Nickens, S. J. Lozano, P. F. Gayaldo, P. J. Polmateer, and P. T. Pinit. 2003. Science-based restoration monitoring of coastal habitats, volume one: A framework for monitoring plans under the Estuaries and Clean Waters Act of 2000 (Public Law 160-457). NOAA Coastal Ocean Program Decision Analysis Series. https://coastalscience.noaa.gov/data reports/science-basedrestoration-monitoring-of-coastal-habitats-volume-one-aframework-for-monitoring-plans-under-the-estuaries-and-cleanwaters-act-of-2000-public-law-160-457/. Accessed 11 Dec 2019.

Thom, C.S.B., M.K.G.L. Peyre, and J.A. Nyman. 2004. Evaluation of nekton use and habitat characteristics of restored Louisiana marsh. Ecological Engineering 23 (2): 63-75. https://doi.org/10.1016/j. ecoleng.2004.06.012.

Tupper, M., and K.W. Able. 2000. Movements and food habits of striped bass (Morone saxatilis) in Delaware Bay (USA) salt marshes: Comparison of a restored and a reference marsh. Marine Biology 137 (5-6): 1049-1058.

Turner, R.E., and B. Streever. 2002. Approaches to coastal wetland restoration: Northern Gulf of Mexico. The Hague, the Netherlands: SPB Academic Publishing. 
United Nations Security Council. 2005. Report and recommendations made by the Panel of Commissioners Concerning the Fifth Instalment of "F4" Claims. https://undocs.org/en/S/AC.26/2005/10.

van der Heide, T., E.H. van Nes, G.W. Geerling, A.J.P. Smolders, T.J. Bouma, and M.M. van Katwijk. 2007. Positive feedbacks in seagrass ecosystems: Implications for success in conservation and restoration. Ecosystems 10 (8): 1311-1322. https://doi.org/10.1007/ s10021-007-9099-7.

van Katwijk, M.M., A. Thorhaug, N. Marbà, R.J. Orth, C.M. Duarte, G.A. Kendrick, I.H.J. Althuizen, E. Balestri, G. Bernard, M.L. Cambridge, A. Cunha, C. Durance, W. Giesen, Q. Han, S. Hosokawa, W. Kiswara, T. Komatsu, C. Lardicci, K.-S. Lee, A. Meinesz, M. Nakaoka, K.R. O'Brien, E.I. Paling, C. Pickerell, A.M.A. Ransijn, J.J. Verduin, and H. Österblom. 2016. Global analysis of seagrass restoration: The importance of large-scale planting. Journal of Applied Ecology 53 (2): 567-578. https://doi.org/10. 1111/1365-2664.12562.

Virgin, S.D.S., A.D. Beck, L.K. Boone, A.K. Dykstra, J. Ollerhead, M.A. Barbeau, and N.R. McLellan. 2020. A managed realignment in the upper bay of Fundy: Community dynamics during salt marsh restoration over 8 years in a megatidal, ice-influenced environment. Ecological Engineering 149: 105713. https://doi.org/10.1016/j. ecoleng.2020.105713.

Warren, R.S., P.E. Fell, R. Rozsa, A.H. Brawley, A.C. Orsted, E.T. Olson, V. Swamy, and W.A. Niering. 2002. Salt marsh restoration in Connecticut: 20 years of science and management. Restoration Ecology 10 (3): 497-513.

Weinstein, M.P., S.Y. Litvin, and V.G. Guida. 2005. Considerations of habitat linkages, estuarine landscapes, and the trophic spectrum in wetland restoration design. Journal of Coastal Research: 51-63.

Weinstein, M.P., S.Y. Litvin, and J.M. Krebs. 2014. Restoration ecology: Ecological fidelity, restoration metrics, and a systems perspective. Ecological Engineering 65: 71-87.

Weinstein, M.P., R. Hazen, and S.Y. Litvin. 2019. Response of nekton to tidal salt marsh restoration, a meta-analysis of restoration trajectories. Wetlands 39 (3): 575-585. https://doi.org/10.1007/ s13157-018-1106-6.

West, J., H. Blanchet, J. Marx, and J. E. Powers. 2016. Update assessment of Blue Crab in Louisiana Waters 2016 Report. http://www.wlf. louisiana.gov/sites/default/files/pdf/page/37756-stock-assessments/ labcassessment2016.pdf. Accessed 11 Dec 2019.

Wickham, D.A., C.C. Kahl, G.F. Mayer, and E. Reinharz. 1993. Restoration: The goal of the oil pollution act natural resource damage actions. Baylor Law Review 45: 405-422.

Williams, G.D., and J.B. Zedler. 1999. Fish assemblage composition in constructed and natural tidal marshes of San Diego Bay: Relative influence of channel morphology and restoration history. Estuaries 22 (3): 702-716. https://doi.org/10.2307/1353057.

Yu, L., Y. Huang, F. Sun, and W. Sun. 2017. A synthesis of soil carbon and nitrogen recovery after wetland restoration and creation in the United States. Scientific Reports 7 (1): 7966. https://doi.org/10. 1038/s41598-017-08511-y.

Zedler, J.B. 2000. Progress in wetland restoration ecology. TREE 15 (10): 402-407.

Zedler, J.B., and J.C. Callaway. 1999. Tracking wetland restoration: Do mitigation sites follow desired trajectories? Restoration Ecology 7 (1): 69-73

Zeug, S.C., V.R. Shervette, D.J. Hoeinghaus, and S.E. Davis. 2007. Nekton assemblage structure in natural and created marsh-edge habitats of the Guadalupe Estuary, Texas, USA. Estuarine, Coastal and Shelf Science 71 (3-4): 457-466. https://doi.org/10.1016/j.ecss. 2006.08.024.

Zimmerman, R., R. Gibson, and J. Harrington. 1979. Herbivory and detritivory among gammaridean amphipods from a Florida seagrass community. Marine Biology 54 (1): 41-47.

zu Ermgassen, P.S.E., J.H. Grabowski, J.R. Gair, S.P. Powers, and J. Jones. 2016. Quantifying fish and mobile invertebrate production from a threatened nursery habitat. Journal of Applied Ecology 53 (2): 596-606. https://doi.org/10.1111/1365-2664.12576. 